\title{
The Development of Market Place Activity Models in Social Sciences Subjects
}

Tika Susanti ${ }^{1,2 *}$, Almasdi Syahza ${ }^{2}$, Suarman $^{2}$

${ }^{1}$ SMP IT Syahruddiniyah, Sei. Pagar, 28473, Indonesia

${ }^{2}$ Faculty of Teacher Training and Education, Universitas Riau, Pekanbaru, 28293, Indonesia

\section{ARTICLE INFO}

Article history:

Received: 08 Mei 2019

Revised: 24 March 2020

Accepted: 29 March 2020

Published online: 24 April 2020

\section{Keywords:}

Development

Product

Market Place Activity

\begin{abstract}
A B S T R A C T
Learning model is very important in the teaching and learning process. The use of the proper model will arouse students' enthusiasm and interest in learning. However, the learning model still has weaknesses that affect students cognitive development, hence it is necessary to develop the learning model. The purpose of this research is to develop a market place activity learning model by using a 4-D model consisting of define, design, development in social science subjects at SMP IT Syahruddiniyah Kampar Kiri Hilir. The respondents were 48 students from class VIIIa and VIIId. Based on data presentation and data analysis, the development of the model carried out is valid. The results value obtained from the aspect of model development $81 \%$, the aspect of model effectiveness $98 \%$, and the aspects of model efficiency $90 \%$.
\end{abstract}

\section{Introduction}

Social Sciences subjects or better known as IPS according to Sakilah (2017) began to be introduced in the 1975 curriculum then determined by the name of Social Sciences (IPS). Whereas, according to Esthi et al., (2017) Social Sciences are subjects of the embodiment of an interdisciplinary approach of several social science concepts that are integrated and simplified for school teaching. These subjects are studied from primary school level up to tertiary level in certain majors or study programs. Therefore, social studies subjects are very important for students, it can be seen since it is started as social studies subjects in the 1975 curriculum.

In education, especially in the learning process according to Amri in Herdini (2018), a positive attitude should be encouraged for students. Therefore it is crucial to use the learning model in the teaching and learning process. The learning model gives the teacher guidelines and references to act systematically in

\footnotetext{
${ }^{*}$ Corresponding author. Tel./Fax.: +62 813-6201-4413

E-mail: tikaannur@yahoo.com
} 
the implementation of learning. The use of learning models will be able to stimulate students to active learning. According to Abu and Joko cited by Hasan (2015) active learning can be seen from two aspects, namely in terms of students, which means that active learning is a process of activities carried out by students in the context of learning. This activity can be physical, mental, or both. There are also more emphasis on mental activity, although to achieve this purpose requires the direct involvement of various physical activities. In addition, the learning model also makes students easier to understand the material provided by the teacher and is able to increase student interest in learning as Erwiza (2019) said that interest in learning can improve student achievement. Therefore teachers must have the ability to innovate in learning that can motivate students to learn more actively, creatively and systematically in solving problems (Arus et al., 2019).

Based on the results of preliminary observations conducted by the researcher at SMP IT Syahruddiniyah Kampar Kiri Hilir, the teacher has sought to improve student learning outcomes, but student learning outcomes are still low. This happens because the teacher's teaching method does not attract students attention that caused student learning outcomes in learning are still low. The market place activity model itself has already been applied by social studies teachers, but the model still has shortcomings that quite affect the learning process, which is easy to cause a commotion when the learning process is in progress, therefore it needs to be improved.

Market Place Activity learning is a type of cooperative learning. Asep Gojwan cited by Syahraini (2017) defines cooperative learning as a learning model that emphasizes the collaborative activities of students in learning in the form of small groups to achieve the same goal by using a variety of learning activities to improve students' ability to understand subject matter and solve problems collectively. It also expressed by Suryani, quoted by Merina (2019) that cooperative learning involves students working collaboratively to achieve learning goals. In this model, students learn by working together in small groups where each group seeks, finds and manages information for sale. The information sold is the material learned that day.

Market Place Activity is also called cooperative learning because teacher only has a role to give instructions and to monitor the learning process. According to Paul (2016) the market place activity model is implemented through a series of timeconstrained stages. According to Sofyan et al., (2017) Market place activity can improve students learning outcomes because students compete to find information to complement their group information. It is also supported by Asmuni (2018) said that implementing learning model of market place activity can increase learning activities and outcomes. Meanwhile, according to Ahmadi in Lisa'diyah (2018) the benefits of market place activity models such as student has responsibility to find information individually, student learns to encourage to promote the results of his/her studies, student learns to pay attention at someone speaks. 
The stages of market place activity according to Paul (2016) are:

1. The first stage, the teacher conveys the learning objectives and displays the tests that will be tested on students.

2. Each group transforms the material into a visual display such as posters using large paper and markers. The poster is limited to a few words, which is a maximum of ten words, no more.

3. Each group determines who will stay and become a "stand guard" and who will go out to the "market" to gather information. The stand guard must advertise his business by shouting the title of the material so that the customer can find his way. The stand guard explains the poster to visitors and is allowed to answer questions raised by visitors.

4. Everyone returns to home base. Those who go to the market to gain information, now take turns teaching what they already know. This is an opportunity to clarify knowledge. Students can return to view the poster or ask quick questions to check details. The goal is that everyone at the end of this stage is ready for the test.

5. All notes, posters and original material are removed.

6. In each group, students combine their thoughts together to see if they can get a complete and accurate answer between them.

In implementing this model there are several weaknesses including 1) causes commotion 2) requires a lot of time 3) requires thorough preparation. To overcome or minimize these weaknesses, it is necessary to make some improvements in the implementation process, specifically reducing the commotion during the learning process. Therefore, in this development, what is done is display the power point of needle direction market cycles which are designated in order to create market activities run well and reduce the commotion that will occur when the buying and selling process takes place. This model is usually easy to make noise because students go to the market without a clear direction that causes sometimes a build up in one stand. With the market cycle, it is expected that market activities will run well and the use of time will be more effective and efficient because students can visit all the stands in the market. Of course, this activity is supervised by a tight time, each group only has a maximum of 5 minutes to visit each shopping stand in the market.

\section{Methodology}

The type of this research is research and development (R \& D). According to Syahza (2016) development research is a research that emphasizes more on explaining and clarifying related to primary data and sources of information obtained. Meanwhile, according to Sugiyono (2012) said research and 
development is defined as a research method used to produce certain products and test the effectiveness of these products. This type of research is using an experimental method with a design only using the experimental class. In this study, researcher used the 4D model. This model was developed by Triangarajan cited in Trianto (2014) which is consists of 4 stages, namely Define, Design, Develop, and Disseminate (Figure 1).

The activity carried out in this study was to develop a Market Place Activity learning model. The flow of Market Place Activity learning model development in social studies subjects are:

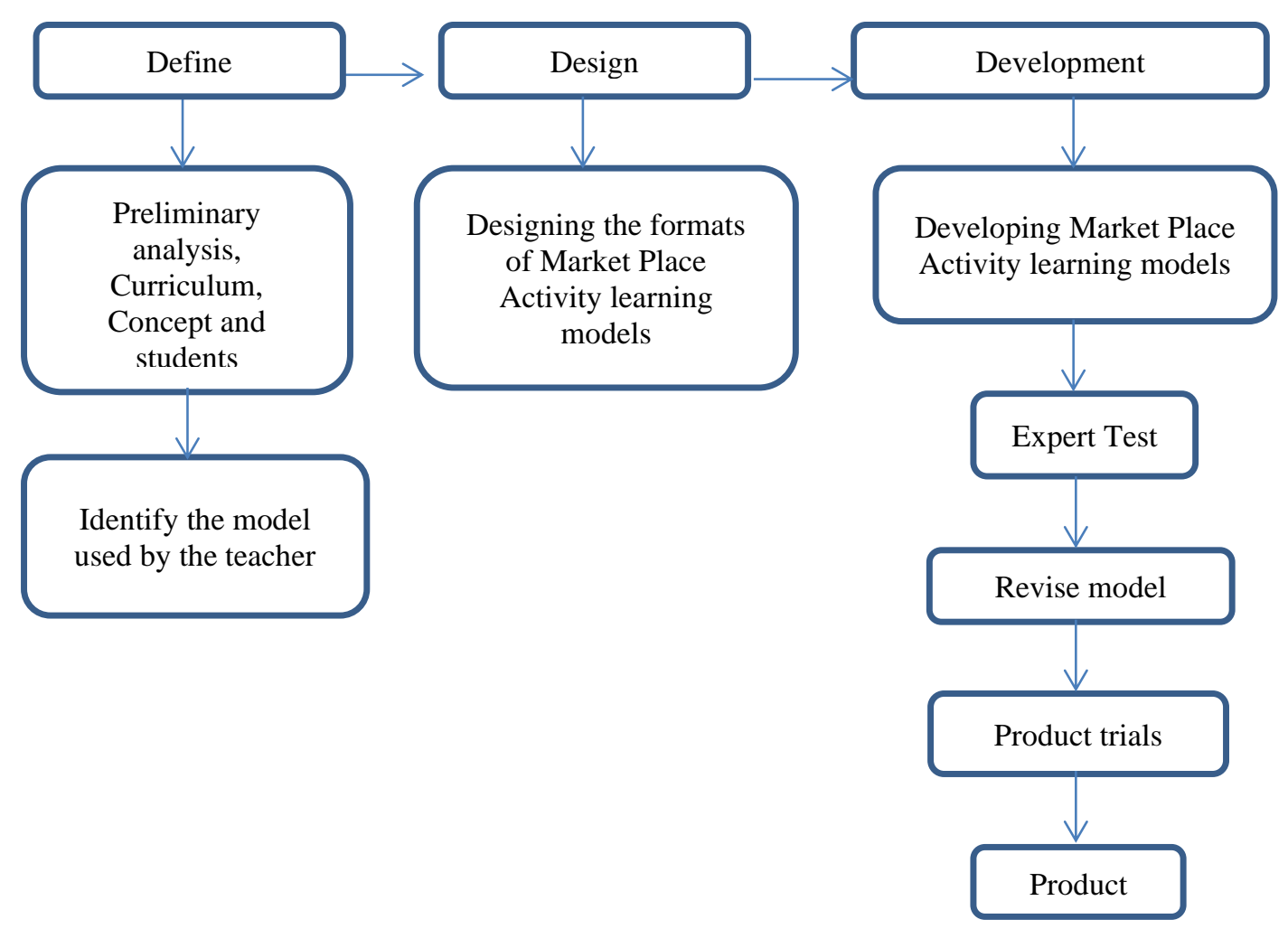

Figure 1. The Flow of Market Place Activity Learning Model Development

The steps in Figure 1 will be explained as follows:

\section{Define Stage}

In this stage there are several focus activities are as follows.

a) Preliminary Analysis

Preliminary Analys is carried out to analyze the needs needed to determine or establish the basic problems faced in learning. 
b) Curriculum Analysis

Curriculum Analysis is a curriculum analysis used by schools. Based on the curriculum, the material will be used and the competencies to be achieved.

c) Students Analysis

Student analysis is a study of student characteristics based on their needs and it development as a reference for the design of learning model development.

\section{d) Concept Analysis}

Concept analysis is a study of concepts that are relevant for the development of social studies learning models. Concept analysis is intended to select, define, detail, and arrange systematically the concepts to be taught in accordance with the learning model.

e) Learning Models Analysis

Learning Models Analysis is a study of the use of learning models used by teachers. In the learning process the use of learning models is very important for the success of teaching and learning in class.

\section{Design Stage}

This stage is designing of learning tools. As for this stage consists of activities such as:

\section{a) Media selection}

Media selection activity is carried out to determine the right media in presenting learning material so that it can clarify the presentation of material and facilitate student acceptance of the material, and can attract students' interest in learning the material.

\section{b) Format selection}

This selection concerns to the format of the learning tool content, the selection of learning models, and learning resources. The result of this design stage is an initial design or design development of social studies learning models. The design of this learning tool is in the form of a syllabus, a lesson plan. Furthermore, the design of this learning tool is developed through expert validation and field trials.

\section{Development Stage}

In this development stage consists of developing the draft 1 tool with validation by experts. Validation activities are carried out by providing learning models and 
validation instruments in the form of study sheets of learning model to experts. The experts who act as validators are lecturers who are experienced in developing learning models. Suggestions from the validators are used as a basis for refinement or revision of the learning model. The activities carried out in validation are as follows.

a) Ask for expert judgment on the feasibility of a learning model design (Draft 1) that has been made. In this case, the expert team is a postgraduateUR lecturer, a social sciences teacher from SMP IT Syahruddiniyah and social sciences teacher from Darma Yudha.

b) Conduct an analysis of the validation results from expert validators.

After validating the design of the learning model (draft 1), then the suggestion from the validators will create a learning model design (Draft 2) which will be conducted field trials then. The trial was conducted with the aim to see the extent of the efficiency and effectiveness of the design of learning tools in the classroom.

\section{Results and Discussion}

The results of the study are the development of market place activity models conducted with the 4-D model in social studies subjects. The model that has been designed is then validated by the validators. After the market place model is developed, 1) explain the learning objectives 2) divide the students into some groups 3) display an example of a market cycle 4) transform the material into a visual display 5) each group advertises its business 6) each group goes to the "market" 7) all return to home base that goes to the market alternately teaches the group that stayed 8) all notes, posters and original material are removed 10) each group concludes the information they got from the market and explains it in front of the class 11) the teacher gives a test 12) the teacher gives a reward. Figure 2 is a picture of the activities of the market place activity model:

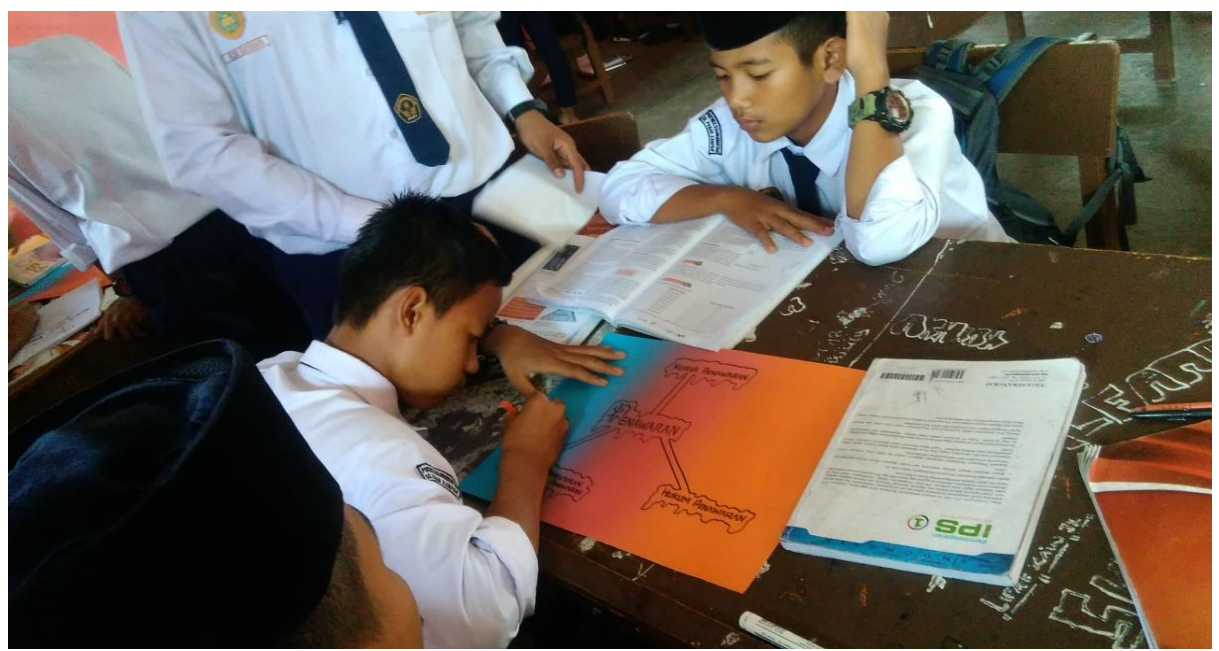

Figure 2: Students make a material framework consisting of at least ten words 


\section{Aspects of Model Development Assessment}

The aspect of model development assessment has 5 components of evaluation aimed to evaluate the basics of model development as sown in Table 1.

Table 1. The aspect of model development assessment

\begin{tabular}{|c|c|c|c|c|c|}
\hline \multirow{2}{*}{ No } & \multirow{2}{*}{ Rated aspect } & \multicolumn{4}{|c|}{ Score } \\
\hline & & 1 & 2 & 3 & 4 \\
\hline 1 & The background of model development is clearly stated & & & & \\
\hline 2 & The objective of model development is clearly stated & & & & \\
\hline 3 & The stages of model development is clearly stated & & & & \\
\hline 4 & The descriptions of the model are clearly stated & & & & \\
\hline 5 & Media used is clearly stated & & & & \\
\hline
\end{tabular}

Overall, the assessment of all validators is in valid category which means it is appropriate to be used in the learning process. The assessment of model development aspect needs to be improved on the development background. In the background it is necessary to explain what information is traded in order to not making students confuse because in draft 1 only explained the market place activity model is a learning model by buying and selling information activities without explaining that the information being traded is the material learned that day. In addition, the model development objectives need to be explained more in detail the steps that are corrected and the purpose of the improvement.

\section{Aspects of Model Effectiveness Assessment}

Model effectiveness assessment has 4 components of evaluation aimed to evaluate the effective use of the model, that is the use of the model can achieve the objectives of the planned learning, as sown in Table 2.

Table 2. Model effectiveness assessment

\begin{tabular}{cllll}
\hline \multirow{2}{*}{ No } & \multicolumn{1}{c}{ Rated aspect } & \multicolumn{3}{c}{ Score } \\
\cline { 3 - 4 } & & & 2 & 3 \\
\hline 1 & This model is easy to use in the learning process & & \\
2 & Models can make students easy to learn & & \\
3 & Models can improve communicative learning & & \\
4 & Models can increase student knowledge & & \\
\hline
\end{tabular}

The assessment of all validators is in valid category which means it is appropriate to be used in the learning process. Validator suggests that when the model development is applied, use material that is not too dense or too much so that the use of the model can be implemented thoroughly. 


\section{Aspects of Model Efficiency Assessment}

Model efficiency assessment has 3 components of evaluation aimed to evaluate the implementation of the model efficiently, those are all the steps of the learning model are carried out well by using the maximum available time and able to complete the material being studied, as shown in Table 3.

Table 3. Model efficiency assessment

\begin{tabular}{|c|c|c|c|c|c|}
\hline \multirow{2}{*}{ No } & \multirow{2}{*}{ Description } & \multicolumn{4}{|c|}{ Score } \\
\hline & & 1 & 2 & 3 & 4 \\
\hline 1 & This model uses adequate time for interaction & & & & \\
\hline 2 & This model uses sufficient time to study the material & & & & \\
\hline 3 & $\begin{array}{l}\text { The steps of the model give a positive impression that can } \\
\text { attract interest in learning }\end{array}$ & & & & \\
\hline 4 & This model can improve student understanding & & & & \\
\hline
\end{tabular}

Overall, the assessment of all validators is in valid category which means it is appropriate to be used in the learning process. The assessment of the use of time on the model for interaction and to study the material must be explained in more detail at the stages of the market place activity model. After the validation process is complete, then rate the average of the validation results is sought so that the revised market place activity model is feasible to use. Table 4 will present a recapitulation of the three aspects of the assessment conducted by 5 validators.

Table 4. Aspects of the market place activity model assessment

\begin{tabular}{ccccc}
\hline No & Validator & Model Development & $\begin{array}{c}\text { Rated Aspect } \\
\text { Model } \\
\text { Effectiveness }\end{array}$ & Model Efficiency \\
\hline 1 & Validator 1 & $80 \%$ & $100 \%$ & $83 \%$ \\
2 & Validator 2 & $80 \%$ & $100 \%$ & $83 \%$ \\
3 & Validator 3 & $80 \%$ & $100 \%$ & $100 \%$ \\
4 & Validator 4 & $80 \%$ & $100 \%$ & $83 \%$ \\
5 & Validator 5 & $85 \%$ & $88 \%$ & $100 \%$ \\
& Avarage & $81 \%$ & $98 \%$ & $90 \%$ \\
\hline
\end{tabular}

From the recapitulation in Table 4 it can be seen that the assessment of the three aspects given by 5 validators has been categorized as valid, it is successively having $81 \%, 98 \%$ and $90 \%$ eligibility. The average rating of all aspects is $90 \%$ with a valid category. This market place activity is able to improve student learning outcomes is in line with a research conducted by Agustina (2016) that the learning tool developed namely problem-based learning model (PBM) is effective in supporting learning activities so that cognitive products of learning outcomes achieve mastery of learning outcomes.

\section{Define Stages}

In this study the defining stage is adjusted to the needs of research, that is the development of market place activity models to improve student learning 
outcomes. At this stage the researcher conducted interviews with teachers about the use of learning models and literature studies about learning models. The results is the model used by the teacher so far in the learning process has not maximally increased student learning outcomes.

\section{Design Stages}

At the design stage the researcher makes the preliminary design of the market place activity learning model by making the steps of learning model that follows the market place activity model. The first thing to do is to select the media that is suitable with the characteristics of the model and then to develop the syntax of the learning model which according to the researcher needs to be developed based on the preliminary studies that have been carried out.

\section{Development Stages}

In this development stage consists of developing the draft 1 tool with validation by experts. Validation activities are carried out by providing learning models and validation instruments in the form of study sheets of learning model to experts. The experts who act as validators are lecturers who are experienced in developing learning models. Suggestions from the validators are used as a basis for refinement or revision of the learning model. The activities carried out in validation are as follows: Asking for the expert judgment on the feasibility of a learning model design (Draft 1) that has been made, and conducting an analysis of the validation results from expert validators. In this research, the researcher followed the 4-D development model which consisted of four steps, namely define, design, development and disseminate. However, the last step, disseminate, was not carried out considering the time spent on this stage was quite long, this became an obstacle for the researcher so that this research only reached the development stage or limited field trials.

\section{Conclusion}

Based on the results of the expert validator assessment, it can be concluded that the development of the market place activity model is appropriate for the learning process. Where the values obtained in a successively are $81 \%$ of the aspect of model development, $98 \%$ of the aspect of model effectiveness, and $90 \%$ of the aspects of model efficiency.

\section{References}

Agustina, F. (2016). Pengembangan Perangkat Pembelajaran Konsep Pencemaran Lingkungan Menggunakan Model Pembelajaran Berdasarkan Masalah Untuk Sma Kelas X . EduSains, 4(2), 94-103 
Arus, G., Seragih, S., \& Kartini. (2019). Effectiveness of Learning with Scientific Approach in Cooperative Model of STAD-based Type Lesson Study. Journal of Educational Sciences, 3(2), 249-259.

Asmuni. (2018). Penerapan Model Pembelajaran Market Place Activity Untuk Meningkatkan Aktivitas Dan Hasil Belajar Pendidikan Agama Islam Dan Budi Pekerti Siswa Kelas Xi Ms-1 Sma Negeri 1 Selong. Jurnal Tarbiyah Islamiyah: Jurnal Ilmiah Pendidikan Agama Islam, 8(1). 59-66

Erwiza, Kartiko, S., \& Gimin. (2019). Factors Affecting the Concentration of Learning and Critical Thinking on Student Learning Achievement in Economic Subject. Journal of Educational Sciences, 3(2), 205-215.

Esthi, S. N., \& Emy, W. (2017). Penerapan Model Pembelajaran Kooperatif (Cooperative Learning) Tipe Make-A Match Berbantuan Media Komik Interaktif Untuk Meningkatkan Aktivitas Belajar Dan Hasil Belajar Ips. Jurnal Pendidikan Surya Edukasi (JPSE), 3 (1), 66-74

Hasan, B. (2015). Penerapan Pembelajaran Active Learning Untuk Meningkatkan Hasil Belajar Siswa Di Madrasah. Jurnal Pendidikan Pedagogik, 1 (1), $34-46$.

Herdini. (2018). Development of interactive multimedia based on Lectora Inspire in chemistry subject in junior high school or madrasah tsanawiyah. Journal of Educational Sciences. 2 (1), 46-55.

Lisa'diyah, M. (2018). Implementasi Metode Pembelajaran Pendidikan Agama Islam (Pai) Di Sekolah Menengah Atas Negeri 11 Bandung. Jurnal Penelitian Pendidikan Agama dan Keagamaan, 16 (1), 110-123

Merina, P. (2019). Student Tutoring, Facilitator and Explaining Models: A Problem Solving Metacognition towards Learning Achievements of Informatics Students. Journal of Educational Sciences, 3(2), 145-154.

Paul, G. (2016). Trik dan Taktik Mengajar. Jakarta: PT. Macana Jaya Cemerlang

Sakilah. (2017). Pembelajaran Ilmu Pengetahuan Sosial. Pekanbaru: Publishing and Consulting Company

Sofyan, E., \& Virgantyani, S. (2017). Pengaruh Model Pembelajaran Market Place Aktivity Terhadap Prestasi Belajar Siswa di SMP PGRI Kota Cimahi. Jurnal Iimiah. 4 (2), 115

Sugiyono. (2012). Metologi Penulisan Pendidikan. Bandung: Alfabeta

Syahraini, T. (2017). Metode Cooperative Learning dalam Pembelajaran Pendidikan Agama Islam. Jurnal Al-hikmah, 14(1), 1-16.

Syahza, A. (2016). Metodologi Penelitian. Pekanbaru: UR Press

Trianto. (2014). Model Pembelajaran Terpadu: Konsep, Strategi, dan Implementasinya dalam kurikulum Tingkat Satuan Pendidikan(KTSP). Jakarta: PT. Bumi Aksara

How to cite this article:

Susanti, T., Syahza, A., \& Suarman. (2020). The Development of Market Place Activity Models in Social Sciences Subjects. Journal of Educational Sciences, 4(2), 426-435. 